\title{
Antropologie a naturalismus
}

\author{
Karolína Drcmánková \\ Ústav etnologie, Filozofická fakulta, Univerzita Karlova, nám. Jana Palacha 2, 11638 Praha 1, Česká republika
}

Do redakce doručeno 11. prosince 2018; k publikaci přijato 24. května 2019

\begin{abstract}
ANTHROPOLOGY AND NATURALISM
ABSTRACT The aim of the text is focus on the critical reflection of postmodern approaches and the form of interpretativist research in the field of anthropology from the point of view of the philosophy of science based on the natural science approach. We point out the pitfalls that the postmodern concept brings and as a corrective we present a conception based on naturalistic approach on the findings of the philosophy of science. Although anthropology draws on a philosophical basis, naturalism in the methodology of anthropological research has so far not been fully taken into account. The aim is to fill this gap and to show the importance of incorporating the natural approach to the study of human behavior, especially in anthropological field research. In the text we summarize the main areas with which anthropology works. We will show the current approach to studying these areas and how these areas can be enriched by a naturalistic view.
\end{abstract}

KEY WORDS Naturalism; Interpretativism; Anthropological Research; Methodology; Epistemology

ABSTRAKT Cílem textu je zaměřit se na kritickou reflexi postmoderních př́stupů a podobu interpretativistického výzkumu na poli antropologie z pohledu filozofie vědy zakládajícím se na naturalistickém př́stupu. Poukážeme na úskalí, které postmoderní pojetí přináší, a jako korektiv předložíme koncepci, jež vychází z naturalistického pojetí opřeného o poznatky z filozofie vědy. Přestože antropologie čerpá z filozofického základu, naturalismus nebyl v metodologii antropologického výzkumu doposud zcela zohledněn. Cílem je tuto mezeru vyplnit a ukázat, jaký význam může mít začlenění naturalistického přístupu při zkoumání lidského jednání, zejména potom při antropologickém terénním výzkumu. V textu shrneme hlavní oblasti, s nimiž antropologie pracuje. Ukážeme současný přístup ke studiu těchto oblastí a jakým způsobem lze dané postupy obohatit o naturalistický pohled.

KL'ÚČOVÉ SLOVÁ Naturalismus; interpretativismus; antropologický výzkum; metodologie; epistemologie

\section{ÚVOD}

Text $^{1}$ se zakládá na interdisciplinárním př́stupu ke studiu člověka tím, že propojuje kvalitativní metodologii antropologického výzkumu s naturalismem. Předkládaná práce čerpá především z filozofického základu, kdy je cílem aplikovat poznatky z filozofie jazyka do metodologie antropologického výzkumu zakládajícím se na interpretativním př́istupu. V sedmdesátých letech dvacátého století se do antropologie etabloval nový metodologický přístup - postmodernismus. Ačkoli byl

1 Text vnikl v rámci projektu Naturalizovaná metodologie antropologického výzkumu, řešeného na Filozofické fakultě Univerzity Karlovy jako Vnitřní grant 2018. postmodernismus ve filozofii podroben značné kritické reflexi, na poli antropologického bádání našel své místo a v současnosti je dominantním metodologickým přístupem. Studie poukáže na úskalí postmoderního přístupu a předloží koncepci, která je $\mathrm{v}$ souladu s naturalistickým pojetí především W. V. O. Quina.

Filozofická témata týkající se otázek ontologických mají nepochybně praktické implikace pro antropologický výzkum. Antropologie více než jiné sociální obory vyžaduje spolupráci s ostatními vědeckými disciplínami. Interdisciplinární přesah se objevuje ve všech odvětvích antropologického zkoumání. Antropolog při své práci využívá nejenom common sense, ale také se opírá o poznatky ze současné vědy, at' už se jedná o biologii, jazykovědu nebo psychologii. Dohromady tak vy- 
tváří nástroje ke zkoumání lidského subjektu v sociálním prostředí. Jsme schopni odhalovat a interpretovat jednání na základě obecných zákonů a znalostí o zásadách lidského myšlení a jednání, je to nástroj, který slouží jako aplikátor k porozumění ostatních. Stejně tak prrírodní vědy, jež jsou vzájemně konzistentní, tj. vycházejí ze svých vzájemných poznatků díky tomu, že jsou zakotveny ve stejné materialistické ontologii. Materialistická ontologie se zakládá na kauzálních a fyzických zákonitostech. Cíl argumentace bude směřovat k obhájení tvrzení, že ústředním zájmem antropologie by mělo být kauzální vysvětlení kulturních faktů. Naturalistický prrístup usiluje o hledání a popisování kauzálních zákonitostí, generalizování empiricky získaných poznatků a falzifikaci teorie, která předchází vědeckému výzkumu. Základním přístupem ke zkoumání světa je ontologický naturalismus, tj. existence pouze jedné objektivní reality, která je nezávislá na mysli jedince, a s tím související metodologický naturalismus, tj. poznatky o vnějším světě získávané za pomoci metodologie př́rodní vědy.

\section{KRITICKÁ REFLEXE NATURALISMU A INTERPRETATIVISMU}

Postmoderní přístupy ve filozofii byly podrobeny značné kritice ze strany naturalistů. $\mathrm{V}$ sociálních vědách však postmodernismus získal své místo zejména proto, že svými tezemi podporoval myšlenky, které byly formovány dávno před postmodernismem na poli antropologického bádání. Jedná se zejména o myšlenku relativismu, jež byla mnohokrát zpochybněna ve 20 . století analytickými filozofy. O silnou kritiku se zasloužil Donald Davidson a Alex Rosenberg. Když Davidson napsal „On the Very Idea of a Conceptual Scheme" (Davidson 2006), zpochybnil v tomto textu tzv. třetí dogma empirismu, tj. rozdělení na formu a obsah. Mohlo by se zdát, že jeho argumenty utlumily myšlenku relativismu. Už ve svém ranějším spise "Čím se mysl zabýváa (Davidson 2004) částečně zmiňuje, jak neuchopitelná myšlenka relativismu je. Tvrzení spočívá v tom, že pokud máme jednu myšlenku či nějaký výrok, je možno je interpretovat různými způsoby. Vzhledem $\mathrm{k}$ tomu, že se každá myšlenka nebo výrok vždy vztahují $\mathrm{k}$ nějakému objektu, musejí být i různé interpretace vztažené k určitému objektu. Své tvrzení obhajuje na př́ikladu dvou různých stupnic užívaných při měření jednotek teploty, tj. Celsiovy a Fahrenheitovy (Davidson 2004, 88).

Ve druhé polovině dvacátého století v návaznosti na modernitu došlo k nahrazení darwinovských idejí novými postmoderními imperativy. Tento model reagoval na změny, které přinesla druhá světová válka. Jedná se o protiklad k pozitivismu a evolucionismu (Doherty - Graham - Malek 1992, 27). Mezi zastánce relativismu patří např́klad R. Rorty, T. Kuhn, David Bloor a B. Barnes. Rorty prosazuje myšlenku různých epistemických systémů, kdy není možné určit, který z nich je správný. Podle Rortyho nemá smysl prŕstup či teorii považovat za nevědeckou, iracionální nebo nelogickou. Vzhledem k odlišnosti epistemických systémů totiž nemůžeme bezpečně určit, která je oprávněná, pravdivá, stejně tak jako přesvědčení (Boghossian 2007, 30).

Alex Rosenberg, jenž je významným kritikem interpretativistických př́stupů $\mathrm{v}$ sociálních vědách, si pokládá základní otázku „Jak je možné, že sociální vědy nedosahují takového pokroku jako vědy přírodní?" (Rosenberg 2012, 21). Úspěšnost sociálních věd za vědami prírodními zcela jasným způsobem zaostává. Stačí se podívat na kritéria hodnocení výzkumů z pohledu vědců přírodních a vědců sociálních. Rosenberg se otázkou tzv. zaostalosti sociálních věd zabývá hned v několika publikacích. Co shledává v sociálních vědách jako problematické, je př́lišné zaměření na subjekt a kladení důrazu na kognitivní kontrolu subjektu. Epistemický empiricismus by neměl poskytovat takový vliv na kognitivní kontrolu, a naopak by se měl zaměřovat na zkušenosti, které jdou nad rámec této kontroly (Rosenberg 1980, 13).

I vědecký př́stup byl napaden vlnou kritiky, a to ze strany postmodernismu. Mezi těmito dvěma př́stupy existuje propast, která je značná hlavně v oblasti epistemologie. Z epistemického úhlu pohledu nemůže být antropologie nikdy vnímána jako věda vzhledem ke svému předmětu zkoumání, jímž je subjekt. V př́ípadě lidského subjektu je nemožné docílit takových poznatků, které by směřovaly k objektivní pravdě. Dalším argumentem je tvrzení, že věda je pouze iluzorní tento argument vychází především z nadřazenosti západních sociálních skupin, čímž ukazují na podřadnost utlačovaných skupin, tj. lidí z oblastí třetího světa. Tímto se postmodernisté vymezují vůči západní racionalistické tradici (Spiro 1996, 764). Tato tradice př̀ použití filozofické terminologie vychází z metafyzického realismu, kdy jazyk slouží jako nástroj pro sdílení významů ve světě, to znamená, že jazyk má referenční funkci. Podle postmodernismu jsou interpretace a zkoumání sociální skupiny založeny na odhalování významu. Analogie mezi odhalováním významu jakožto nástrojem, jenž slouží porozumění zkoumanému subjektu $\mathrm{v}$ naturalistickém a interpretativistickém pojetí, souvisí s teorií významu a pojmem pravdy. Intersubjektivita je nástroj pro odhalování významu $\mathrm{v}$ naturalismu, naopak potom $\mathrm{v}$ postmodernismu se o intersubjektivitu nelze spolehlivě opřít.

Dalo by se říci, že by nás směrovala $\mathrm{k}$ ještě větší propasti. $\mathrm{V}$ případě, že budeme lidské poznání a pravdu² relativizovat v závislosti na kultuře, etnickém původu, rase nebo společenském postavení, dostaneme se do pasti, která bude obdobná pojetí etnocentrismu. Pravda by se měla odvíjet od empirie, abychom mohli říct, že existují platná kritéria pro odhalení významu, jak objektivní, tak intersubjektivní (Spiro 2009, 765). Jedině na základě platných kritérií jsme schopni hodnotit, co je pravdivé a co nikoli. Pokud však žádná taková kritéria neexistují, nelze o pojmu pravdy vưbec mluvit a tím není možné se dobrat jakéhokoliv druhu poznání. S předpokladem existence objektivní reality by vědomosti nemohly být chápany jako vykonstruované, ale jako objektivní. Navzdory problematičnosti pojmu pravdy nelze pravdu chápat jako relativní pojem (Ruse 1995).

2 Ve smyslu opodstatněného jednání, tj. je možné se opř́it o objektivní fakta. 
Vraṫme se zpět $\mathrm{k}$ etnocentrismu. V antropologických teoriích je myšlenka etnocentrismu prezentována jako směr, který vyzdvihuje západní společnosti, v jejichž světle jsou ostatní společnosti degradovány na méně vyspělé, primitivní nebo méněcenné.

Podle postmodernismu „...neexistují žádné objektivní di̊vo$d y$, proč preferovat západní racionalismus na úkor jiných tradic. Věda je forma dominance, která je zřejmá $v$ antropologii $v$ př́padě asymetrie moci, jejímž projevem je rasismus, etnocentrismus" (Rorty 2012, 203).

Richard Rorty, ačkoliv je jeho přístup do jisté míry relativistický, se sám považuje za anti antietnocentristu (Rorty 1990, 57). Z jeho pohledu to znamená, že lze nahlížet na etnocentrismus i pozitivně. Etnocentrismus je sice chápán $\mathrm{z}$ pohledu nadřazenosti západní společnosti, nicméně upozorňuje, že západní společnost je jinakosti otevřená právě proto, že na ni umožňuje nahlížet, nikoli se nad ni povyšovat (Rorty 1979). $\mathrm{V}$ návaznosti na to se domníváme, že naopak relativismus může být tou dvousečnou zbraní, která může na tuto jinakost pohlížet s oním nežádoucím despektem. Kulturní relativismus nás nabádá $\mathrm{k}$ tomu, abychom se vyhnuli etnocentrismu. Nicméně ani relativistické pojetí nás nemůže přivést $\mathrm{k}$ bezchybné interpretaci, naopak ji učiní nemožnou, protože není možné interpretovat něco, co je natolik odlišné od toho, co je nám známo. Toto stanovisko nemá $\mathrm{v}$ žádném př́ípadě za úkol hájit etnocentrismus. Nástroj, jenž nám umožní se etnocentrismu vyhnout, je nasnadě. Jedná se o to, co Davidson nazývá principem vstřícnosti. To znamená, že je možné odmítnout relativismus a zároveň se vyhnout onomu tolik kritizovanému etnocentrismu přijetím dvou zásad: 1) přijmout myšlenku existence objektivní reality a 2) interpretovat mluvčí jako racionální, ale podle našich standardů.

Postmodernismus odmítá všechny postuláty vycházející z naturalistického př́stupu a argumentuje, že vědy, které se zabývají lidským subjektem, nemohou být hodnoceny stejným měřítkem jako vědy přírodní. Není možné nalézt pravdu objektivní ani intersubjektivní. Antropologie tedy nesplňuje př́sná vědecká kritéria, ale může sloužit jako nástroj k objevování významů. Odhalování významů se zakládá na důkladné textové analýze, díky níž lze odhalit i skrytý kontext. To však vylučuje možnost odhalit význam na základě kauzálního vysvětlení, které je pro vědu signifikantní. Pokud by antropologie následovala logiku př́rodních věd, jejichž předmět zkoumání má kauzální vysvětlení, mohla by pozvednout svou hodnotu a stát se vědou.

Nelze zpochybnit rozdíly, které se napříč lidskými společenstvími objevují, ale je třeba zmínit, že takové rozdíly nejsou natolik radikální, aby zabránily antropologům pochopit jiné společnosti. Můžeme pochopit myšlení druhých na základě vlastních zkušeností a můžeme odhalit výrazy na základě evidence, kterou máme pro své vlastní jednání. Věda je podle postmodernistů pouze vyprávěním př́běhu, kritéria pro hodnocení mohou být pouze subjektivní.

Na základě kladení důrazu na text, jeho subjektivní interpretaci a zpochybnění autority autora je ve finále text nahližen jako otevřený jakékoliv další interpretaci. Výpověd' autora tedy nemá přiliš vysokou hodnotu, ne-li zcela žádnou. Jestliže však potlačíme autoritu antropologa jakožto vědce, stane se potlačenou i vědecká hodnota antropologického bádání.

Argumentem, který slouží ve prospěch interpretativismu a pro vyvrácení výše zmíněných tvrzení, jsou dvě základnílidské složky, jež nejsou potřebné při studiu fyzických objektů - empatie a vhled. Lidské propozice, zájmy a touhy jsou kulturně podmíněny, protože se vztahují vždy k prostředí, ve kterém jedinec žije. Tyto touhy se transformují do významů, jež jsou kulturně relativní. Vzhledem tomu, že se kultury od sebe odlišují, někdy i velmi radikálně, jsou významy nesouměřitelné. Mysl a kultury jsou objektivně neprůhledné, neexistuje žádný způsob, kterým bychom mohli odhalit obsah mysli a proniknout do kultury, jež je spletená z pavučiny významů. Jelikož prací antropologa je odhalovat významy a odhalování těchto významů je natolik problematické $\mathrm{v}$ očích postmodernistů, není možné provádět nic jako antropologický výzkum či cokoliv jiného.

Problém postmoderní antropologie spočívá ve velmi tenké hranici toho, co je možné považovat za beletrii, populární antropologii a vědeckou disciplínu: antropologii (Clifford, Marcus 1986, 34). Vrat’me se znovu ke klíčové antropologické úloze, tj. interpretaci. V následující kapitole se zaměříme na její interpretativistickou podobu.

V následující části si ukážeme argumenty, proč se domníváme, že by antropologické bádání mělo směřovat $\mathrm{k}$ naturalistické koncepci. V jednotlivých částech osvětlíme dané oblasti zkoumání, o které se opírají poznatky v rámci antropologického výzkumu, a ukážeme, jak by mohla vypadat jejich naturalizovaná podoba, př́padně korekce některých přístupů. $\mathrm{V}$ první řadě se podívejme, jakým způsobem je definovaná věda a proč její současná postmoderní podoba ztrácí status vědy.

\section{ANTROPOLOGIE JAKO VĚDA}

Kritika sociálních věd spočívá v tvrzení, že tyto zaostávají ve svých poznatcích výrazně za vědami přírodními, případně že je u nich zřejmá absence pokroku. Věda má nastavená pravidla, která jsou osvědčená, vědci dodržovaná, a na základě těchto normativních přístupů jsme schopni generovat relevantní a objektivní výsledky zkoumání (Rosenberg 2012). Věda se zakládá na něčem, co můžeme pozorovat a kontrolovat. Nejzákladnější a nejvýznamnější metodologický nástroj je testování hypotéz. Uved’me př́iklad lidského jednání, který sám o sobě ukazuje, jakým zpo̊sobem věda pracuje. Na základě nějaké evidence je formována hypotéza, která má formu $k d y z ̌ X$, tak $Y$. To znamená, vím, že když hřmí, pravděpodobně bude i pršet - tuto hypotézu potom mohu libovolně testovat vždy, když zahřmí, a pozorovat, zda začne pršet. Pokud budu tuto hypotézu testovat dostatečně dlouho a vždy se mi potvrdí, získávám tak informaci, že kdykoliv zahřmí, bude i pršet. Vědeckému zkoumání vždy předchází teorie, která se vyznačuje logickou koherentností, je vnitřně konzistentní a některé $\mathrm{z}$ jejích teoretických konceptů jsou měřitelné. Vědecká teorie formuje hypotézy, jež jsou ověřitelné, tj. je možné je verifikovat nebo falzifikovat (Kuznar 2008, 5). 
Nejenom o vědě můžeme říct, že zkoumá poznatky o světě tímto způsobem. Takové postupy používají lidé běžně v každodenním životě, aby získali informace o světě, ve kterém se nacházejí. A co víc, jsou schopni tyto informace přizpůsobovat změnám, které $\mathrm{v}$ jejich prostředí nastávají, tj. adaptativně reagovat na např́klad změnu klimatických podmínek (Alcock 2003, 84). Postup je zcela intuitivní a přirozený když nastane nějaká událost, pozorovatel se snaží zjistit, co se stalo, a na základě toho formuje hypotézu. Z takové hypotézy může předvídat událost, jež by mohla nastat v budoucnu. Docházíme k deskriptivnímu popisu na základě empirických dat. Tento postup je nazýván „popisnè-kauzální generalizace“ (Kincaid 2012, 85).

Neméně významnou roli v budování vědeckých hypotéz hraje teoretické zázemí, ze kterého zkoumání vychází. Sociální vědy, nevyjímaje antropologii, vycházejí ve svých bádání, ze systematických empirických poznatků, za kterými se nacházejí i kauzální vztahy.

Antropologické zaměření na kulturní prvky, které dominují v antropologickém výzkumu dvacátého století, se soustředí na „... normy, hodnoty, přesvědčení jako na hlavní kulturní prvky“ (Kincaid 2012, 378). Ke všem těmto kulturním prvkům je možné přistupovat jako ke kulturním modelům, jež mají v rámci společnosti jisté systematické uspořádání. Kulturní modely tvoří koherentní celek, který stejně jako většina systémů vychází z kauzálních zákonitostí.

Všechny abstraktní entity jsou spojené s empirickými fenomény, které jsou kauzálně vysvětlitelné a testovatelné (Kuznar 2008, 173). Ukázali jsme, že současným př́stupům v rámci antropologie, ale i jiných sociálních věd, schází kauzální přístup ke zkoumání sociálních aktérů. Dalším nedostatkem, jenž je markantní v sociálních vědách, je absence empirické generalizace.

Domníváme se, že antropologie by v mnoha ohledech mohla čerpat $\mathrm{z}$ naturalistického př́stupu, zejména co se týče znaků vědeckosti. Hlavní bod, s nímž je potřeba pracovat, je existence jednoho nezávislého světa. Pro tento svět máme evidenci, nemůžeme předpokládat existenci jiných světů či světů, které se nacházejí v myslích jedinců. Jedním $\mathrm{z}$ důvodů, proč se domníváme, že je tato myšlenka neudržitelná, je existence intersubjektivity. Pokud bychom každý žili ve vlastním světě, nemohli bychom si vzájemně vưbec porozumět a ani se na jistých věcech shodnout. Zejména se jedná o objekty, př̀edměty a významy, které jsou veřejně dostupné. Kuznar zmiňuje, že ačkoliv naturalismus odmítá existenci nadpřirozených entit, neznamená to, že by antropologové měli svưj zájem směřovat pouze k empirickým fenoménům.

"Jakýkoliv fenomén, který mưže být empiricky definován a spolehlivě měřen, tj. náboženské ideje, sociální vztahy, emoce, kognitivní schopnosti, a dokonce i změněné stavy vědomí, lze vědecky studovat." (Kuznar 2008, 173). I abstraktní entity se vztahují vždy k nějakému fyzickému objektu, proto je možné tyto fenomény zkoumat empiricky.

Můžeme říci, že přijetím naturalismu se vracíme zpět $\mathrm{k}$ pozitivistickým př́stupům. Pokud budeme nadále následovat myšlenky filozofů, jako byli Quine a Davidson, je třeba zmí- nit, že se pozitivismus od naturalismu v určitých ohledech odlišuje (odmítnutí rozdělení mezi analytickými a syntetickými soudy ${ }^{3}$ ), tak se dostaneme čistě k empirické zkušenosti a odmítneme rozdělení mezi schématem a obsahem ${ }^{4}$, čímž se zbavíme myšlenky na relativismus. Je důležité si uvědomit, že jedním $\mathrm{z}$ nejdůležitějších bodů naturalismu je interpretace pozorovatelného chování - proto svou pozornost přeneseme $\mathrm{k}$ behaviorismu $\mathrm{v}$ naturalistickém pojetí.

\section{BEHAVIORISMUS A ANTROPOLOGIE}

Antropologie je disciplína, jejímž úkolem je interpretovat lidské subjekty. Abychom docílili co nejpřesnější interpretace, je základním předpokladem porozumění. Interpretace potom vychází z pozorování těch, které chceme interpretovat. $\mathrm{V}$ předchozích kapitolách jsme ukázali, jak naturalistická pozice poskytuje jasný vhled do fungování mysli na základě kauzálního působení na fyzické tělo, jenž zapř́ičiňuje určité jednání.

Neodmyslitelnou roli při interpretaci hraje behaviorismus. Již Quine upozorňoval na důležitou roli behaviorismu, kterou dokazoval ve svých myšlenkových experimentech, a poukazoval i na vliv behaviorismu ve vědě. Quine se domnívá, že jediné, co máme $\mathrm{k}$ dispozici, je pozorovatelné chování a na základě jak verbálních, tak neverbálních projevů můžeme získávat poznatky o světě a ty následně ověřovat, ostatně stejně tak jako věda. (Quine 2012)

Chování je sémantickým a epistemologickým základem mentality, bez něhož by nebyl možný pohled do myslí ostatních. Neznamená to, že behaviorismus by umožňoval „číst“ lidskou mysl, ale napomáhá předvídání jednání druhých. Pokud mluvčí tvrdí, že má nějaké propoziční postoje, není důvod pochybovat o tom, že je skutečně má - přítomnost propozičních postojů u člověka považujeme za něco nezpochybnitelného. Podívejme se na Davidsona a jeho přístupy ke zkoumání mysli. Propoziční postoje, které se nacházejí v hlavě subjektu, vždy podléhají tzv. autoritě první osoby. To znamená, že člověk vždy ví, jaká jeho přesvědčení jsou, zkrátka ví, co si myslí, a ví, o čem je přesvědčen (Davidson 2004). Tato sebehodnocení nejsou založena na evidenci, ale někdy z ní může subjekt vycházet. Pokud nám mluvčí sdělí své postoje, nemůžeme vždy s jistotou určit, na základě jaké evidence bylo takové přesvědčení získáno. Davidson zdůrazňuje, že podle autority první osoby to, co mluvčí říká, znamená přesně to, co má v úmyslu:

„... slova mluvčího (obecně) znamenají presně to, co se jimi snaží vyjádřit ... existuje předpoklad - nevyhnutelný předpoklad obsažený v interpretaci - že mluvčí většinou ví, co se snaží vyjádřit. Takže existuje také předpoklad, že pokud má mluvči danou větu za pravdivou, zná její obsah." (Davidson 2006, 250).

3 Quine tuto myšlenku rozpracovává ve článku „Dvě dogmata empirismu“.

4 Davidsonovo třetí dogma empirismu. 
Kognitivní funkce korelují s organizací a sítí neurálních vzruchů. Řada vědeckých studií také poukazuje na přímý kauzální vztah mezi neurálními procesy a mentálními fenomény, které se odehrávají v lidském mozku. Opíráme se o naše smyslové poznání, jež nám podává věrný obraz vnějš́ho světa. Výsledkem přijímání vjemů za pomocí percepce vzniká $\mathrm{v}$ naší mysli obraz, jehož vnímáme jako odraz externího světa (Welsch, Singer, Wunder 2011, 24).

Poznatky zahrnující znalost o myslích ostatních jedinců závisejí na pozorování jejich jednání (Kim 2010, 87). Kdybychom následovali karteziánský dualismus nebo relativismus, tak bychom se připravili o možnost předvídat jednání a „číst“ obsahy myslí jiných lidí, což by zapříčinilo, že by nebylo možné odhalovat významy v intersubjektivní komunikaci a ani by žádný veřejný význam neexistoval. Abychom to shrnuli, bez behaviorální evidence zahrnující i verbální chování je nemožné určit, co si ostatní myslí nebo co cítí. Vycházejme tedy ze současné podoby postmoderní antropologie a položme si pár otázek. Jak můžeme vnímat projevy napríílad bolesti, která je způsobena fyzickému tělu, bez príijmutí kauzality? Jak bychom mohli fungovat $\mathrm{v}$ běžném životě bez předvídání jednání druhých lidí? Není snad naší každodenní praxí interpersonální komunikace a kooperace s ostatními?

Aby bylo možné zodpovědět tyto otázky, domníváme se, že máme jedinou možnost, a tou je následovat naturalistickou koncepci. Vzhledem $k$ tomu, že člověk je entita fyzická a funkce jeho fyzického těla je založena procesech, které jsou totožné s fyzickými procesy, je třeba $\mathrm{k}$ jeho zkoumání přistupovat stejným způsobem. Pokud je chování těchto neoddělitelných složek člověka podmíněno obecnými fyzikálními zákony, pak musí být i lidské jednání rízeno stejnými zákony (Rosenberg 1980, 14). Zkoumání lidských subjektů je umožněno na základě biologických a psychologických předpokladů po odhalení jak významů, tak toho, jaký mají smysl kulturní fenomény pro život člověka. Psychologické fenomény mohou být nahlíženy z hlediska neurologie, tj. zkoumání procesů $v$ mozku a ty jsou neodmyslitelně spjaty s biologií, tj. tělesnou schránkou (Sperber 1996, 18).

\section{ANTROPOLOGIE A NORMY}

V následující části objasníme, jakým způsobem má vliv behaviorismus na formování našich propozic a jak to souvisí $s$ normativitou. Nebude se jednat pouze o koncept normativity v rámci jazykových struktur nebo struktury lidského moz$\mathrm{ku}$, ale ukážeme i roli norem ve společnosti a jaký vztah mají $\mathrm{k}$ antropologii. To, co nás bude zajímat, je, jakou roli hrají normy v lidském chování a jaký je jejich význam v antropologickém zkoumání $\mathrm{z}$ hlediska naturalismu.

V první řadě se podíváme na koncept normativity. Prostřednictvím kauzálního řádu získáváme presesvědčení o světě „kauzální rád je dán vztahem příciny a důsledku “ (Peregrin 2010, 186). Jedná se o propojení objektů, které se nacházejí v časoprostoru, a propozic. Propozice na rozdíl od objektů nepodléhají vztahům kauzálním, ale logickým, tzn. nevycházejí ze zkušenosti, ale podléhají jazykovým normám. Respektive je získáváme na základě zkušenosti, ale procesy, které se odehrávají v našem mozku, jsou založeny na logických vztazích, jako je inference aj. Tyto logické vztahy následují normativní procesy (Peregrin 2000, 187). Společnost funguje na podobném principu. Na základě zkušeností je schopna identifikovat nebezpečné jednání a na jejich základě vytvoří systém pravidel, který slouží jako nástroj pro fungování společnosti. Normy tak slouží jako nástroj, který umožňuje vhled do fungování společnosti. Tento fenomén můžeme posuzovat prostřednictvím zkoumání normativního postoje jedinců, od kterého se odvijí. Členové společenství následují určitá pravidla a tato pravidla nám mohou osvětlit jednak fungování společnosti a jednak důvody, na základě kterých byla tato pravidla formována. Základní tezí naturalismu je, že neexistuje apriorní poznání, tzn. vše je odvozeno ze zkušenosti. Stejně tak to platí i pro normy. Víme, že člověk jedná $\mathrm{z}$ hlediska určitých motivů, které směřují za jedním prostým účelem - přežití. Normy mají korektivní charakter z hlediska zachování společenského řádu, dodržování pravidel se jeví pro jednotlivce jako užitečné. Od Richarda Dawkinse víme, že člověk jedná sobecky za účelem zachování a reprodukce svých genů (Dawkins 2014, 2).

Dủležitým aspektem pro přežití jedince je kooperace ve skupině - poskytuje řešení problému vyskytujíćího se $\mathrm{v}$ rámci společnosti a napomáhá vyhnout se těmto problémům. Nedodržování norem by mohlo narušit fungování společnosti a mohlo by ohrožovat členy společenství. K normám a pravidlům je třeba přistupovat $\mathrm{z}$ pohledu historického. Co se tím rozumí? Jejich formulace proběhla a posteriori, kdy v minulosti poukázala na možné nežádoucí jednání nebo upozornila na nebezpečí. Normy jsou zkušeností opodstatněné, jejich zkoumáním bychom mohli docílit určitého obrázku o zkoumané společnosti vzhledem $k$ tomu, že často odrážejí naše zájmy a hodnoty, nejsou však neměnné (Putnam - Rorty 1997, 46). Mark Colyvan dává do souvislosti normativitu a racionalitu. Své názory obhajuje na základě tvrzení, že hodnocení racionálního jednání se odvíjí od sankcí. Pro racionálně smýšlejícího jedince není výhodné pravidla porušovat. Nedodržení pravidel bývá sankcionováno, at už pokutami, nebo jiným druhem trestu (Braddon-Mitchell - Nola 2008, 20). Kooperace ve skupině umožňuje přežití jednotlivce, v některých případech poskytuje určitou evoluční výhodu, což je jeden z důvodů, proč se naše jednání může jevit jako altruistické (Dawkins $2014,5)$. Jedinec si uvědomuje, že pokud spolupracuje, může se mu jeho investice do spolupráce v budoucnu vyplatit, nedodržováním pravidel však nic nezíská. Normami můžeme rozumět pravdivost, objektivitu, racionalitu, které jsou do určité míry závislé na procesu myšlení každého člověka, a to tím způsobem, že je k těmto hodnotám něco přidáváno, tzn. jedná se o výsledek našeho myšlení, reflexe našich smyslů a leží imanentně $\mathrm{v}$ procesu poznání. $\mathrm{Z}$ hlediska postmodernismu neexistuje nic jako lidská přirozenost a pravda existuje pouze ve vztahu k pozorovateli. Wittgenstein upozorňuje, že je mylná myšlenka propozic jakožto nástroje, který zrcadlí realitu, naproti tomu jsou normy mnohem věrnějším odrazem reality. Následování a dodržování pravidel je antropologickým feno- 
ménem, protože zásadním způsobem ovlivňuje lidské jednání. Dodržování pravidel zajištuje stabilitu společnosti a napomáhá regulaci chyb (Baker - Hacker 2009, 51-53). Existence pravidel je podmíněna lidským faktorem. Vzhledem $\mathrm{k}$ tomu, že pravidla nepodléhají pravidelnostem, není možné je identifikovat na základě detekce pravidelností v chování (Peregrin 2012, 87). Z pohledu naturalismu má smysl zkoumat normativní postoje ve společnosti, protože se zásadním způsobem mohou podílet na obrazu fungování společnosti a některé druhy jednání mohou opodstatnit. Učení se, předávání instrukcí dalším generacím či formulace pravidel a norem se ve společnosti neobejdou bez verbálního projevu.

\section{JAZYK A VÝZNAM}

Otázky zabývající se teorií jazykového významu v rámci antropologického zkoumání jsou diskutovány představiteli lingvistické a interpretativní antropologie, tj. Cliffordem Geertzem, Wilhelm von Humboldtem a dalšími. Teorie významu je $\mathrm{v}$ rámci diskuze dvacátého století ve filozofii významným tématem, kdy řešení otázek spojených s jazykovými kompetencemi a teorií významu zásadním zpơsobem ovlivnilo současné myšlení $\mathrm{v}$ rámci filozofie vědy a mysli. Jedná se o W. V. O. Quina a Donalda Davidsona. V souvislosti s naturalismem a jeho aplikací na jazyk se zaměříme na Pinkerovo pojetí jazyka jako instinktu v oblasti kognitivní filozofie. Pinker je odpůrcem tvrzení, že člověk se rodí jako prázdný nepopsaný list. ${ }^{5}$ Jeho argumentace spočívá v obhajobě biologických dispozic, které jsou vrozené a nezbytné pro učení se jazyku - pokud by je totiž člověk neměl, nemohl by jazykovou kompetencí vůbec disponovat (Pinker 2004). Jakákoliv forma učení vyžaduje přítomnost empirických podmínek. Při osvojování jazyka hraje jednu z nejdůležitějších rolí sémantika. Dítěti totiž nestačí naučit se pouze věty, které jsou mu sdělovány, ale potřebuje je vždy zasadit do určitého kontextu. Dítě neslyší věty v izolaci, ale právě za určitých okolností. Věty referují k objektům, událostem a lidem, v rámci takového kontextu jsou schopni rozpoznávat jazykové významy. Existuje jistá korelace mezi kognitivními schopnostmi člověka a jazykovými schopnostmi. Na základě této korelace implikuje lidské myšlení neverbální reprezentace. Tyto reprezentace slouží k uchování jazykového významu v mysli. $\mathrm{Na}$ jejich základě je člověk schopný intersubjektivně sdílet své poznatky a napomáhají mu i při učení se jiným jazykům. Podle Daniela Dennetta je význam sice veřejnou entitou, ale vždy je obsažen v mysli jednotlivce, který jej extrahuje z toku informací, jež $\mathrm{k}$ němu $\mathrm{z}$ okolního světa směřují. Tento tok je konceptuálně uspořádáván $\mathrm{v}$ mysli, kde slouží k odhadování budoucích situací. Dennett v návaznosti na Quina dodává, že lidská mysl je příliš komplikovaná na to, abychom ji mohli redukovat na fyzickou entitu, jakou je například počítač. Mozek chápe jako sémantický motor složený z několika částí, které

5 Tabula rasa - výraz, který užíval John Locke, Steven Pinker hovoří o „The Blank Slate“. jsou vzájemně propojeny a dohromady tvoří velmi užitečný nástroj pro komunikaci s okolním světem (Dennett 2016).

Jazyk patří neodmyslitelně $\mathrm{k}$ lidské přirozenosti, protože schopnost mluvit je jednou $z$ věcí, bez níž se člověk v každodenním životě neobejde. V otázkách lidské přirozenosti naturalisté dochází k názoru, že právě lidský jazyk je to, co nás odlišuje od ostatních živočišných druhů. Jazyková kompetence zahrnuje nejen užívání jazyka, ale i učení se jazyku a jeho interpretaci (Pinker 1995, 17). Nejedná se o abstraktní nástroj komunikace, ale o biologickou dispozici. Moderní doba je nakloněna různým inovacím a teoriím, které mají pro své argumenty nedostatečnou evidenci - např. teorie, že člověk je zcela ovlivněn a formován kulturou, která odráží svou podobu $\mathrm{v}$ přesvědčeních člověka atd. Jazyk podle Pinkera však není v žádném př́ípadě kulturní artefakt, kterým bychom byli schopni konstruovat realitu nebo bychom neznali jeho gramatická pravidla až do chvíle, než bychom se je naučili ve škole. „Jazyk je komplexní, specializovaná dovednost, která se samovolně rozvijí od dětství bez volní kontroly nebo na základě nějakého požadavku. Rozviji se bez znalosti jeho pravidel. Je kvalitativně stejný u každého člověka a je odlišný od obecnějších dovedností sloužících ke zpracování informací nebo projeviom inteligence." (Pinker 1995, 18).

Jazyk Pinker nepovažuje za psychologickou schopnost ani jej neredukuje pouze na neurální systém, ale považuje jej za instinkt, a to zejména proto, že schopnost mluvit je pro člověka přirozená asi tak, jako pro pavouka uplétat pavučinu. Jazyk je biologickou adaptací, která slouží $\mathrm{k}$ přenosu informací a ke komunikaci s ostatními, jedná se o velmi dobře navržený biologický instinkt. Stejný názor, který Pinker zastává, se objevuje již v Darwinově publikaci The Descent of Man (Pinker 1995, 19).

Podle naturalismu hraje i v jazyce roli kauzalita - je tomu tak i z toho důvodu, že všechny procesy v těle jsou vzájemně propojeny. Kauzální vztahy řídí jednání druhých lidí, vztah subjektu a objektu utváří kauzální spojitost, jež vyvolává určitou reakci. Takové tvrzení se vztahuje i na komunikace mezi lidskými subjekty. Výrazy v jazyce jsou relační struktury, jejichž symboly se týkají konkrétních objektů, událostí a kategorií. Jsme schopni detekovat jejich rozdělení v prostoru a čase a jejich kauzální souvislosti. Tyto kauzální vztahy dávají možnost odhadovat jednání druhých, zároveň jejich přesvědčení a touhy. Na základě jazyka jsme schopni rozlišovat základní ontologické kategorie, mluvit o událostech a rozlišovat role sociálních aktérů. Samostatnou částí jazykové kategorie je pojem pravdy a rozlišování pravdivostních hodnot (Pinker - Bloom 1990, 712).

Bylo řečeno, že pro to, abychom mohli sociální vědy učinit naturalizovanými, měli bychom se zaměřit na zkoumání fyziologických procesů a vlastností, které jsou u člověka do určité míry měřitelné. To znamená, že se znovu obrátíme na filozofii mysli a studium neurálních procesů. Jedním z př́stupů k obsahům lidské mysli je jazyk. To, co je pro antropologii u verbálních projevů nejdůležitější, jsou obsahy slov, které nám mluvčí sděluje. Sémantika je vztah mezi slovy a myšlenkami, ale také mezi slovy a dalšími lidskými záležitostmi, vztah slo- 
va a reality, člověk je schopen druhému porozumět pouze za použití slov. Je to vztah slov a emocí (Pinker 2013, 3). Jazyk je hlavním nástrojem pro předávání pravidel ve společnosti, sám podléhá př́sným pravidelnostem, při jejichž nedodržení může nastat problém, který by mohl zamezit správnému porozumění. Schopnost používat jazyk je závislá na fyziologických vlastnostech, jedná se o práci vokálních částí v lidském těle, o přizpůsobení dýchání a polykání, dekódujeme řeč na základě sluchových schopností a všechny tyto aspekty podle Pinkera ukazují na jazyk jako na fenomén, který se bezpochyby vztahuje více $\mathrm{k}$ biologii než ke kultuře (Pinker - Bloom 1990, 708).

Co z toho vyplývá pro naturalistický pohled na jazyk? Domníváme se, že jazyk je pro antropologický výzkum nezbytný. Abychom mohli zkoumat lidské subjekty, je třeba se zaměřit na jejich verbální projevy. Ačkoliv mohou přinášet výpovědi těchto sociálních aktérů různá úskalí ve formě nepravd, špatného jazykového pochopení, které plyne z nedostatečné jazykové vybavenosti, přesto je to jeden $\mathrm{z}$ mála nástrojů, jenž máme $\mathrm{k}$ dispozici pro vhled do myslí subjektů zkoumání. Jsou tři základní teze, které by v antropologii měly získat své místo: 1) Jazyk je biologická dispozice člověka a zkoumání jazykových projevů by mělo probíhat na základě předpokladu kauzálního působení mezi obsahy myslí a verbálními projevy. Jazykové jednání v sobě zahrnuje i projevy neverbální, ale intencionální. Př́kladem takového jednání je, že mě určitá myšlenka vede $\mathrm{k}$ tomu, abych něco rozbil. Pokud tuto činnost provedu, vyjádřím tím obsah mysli bez verbálního projevu. 2) Proto by se význam měl odvíjet i o nám dostupné evidence. 3) Výpovědi sociálních aktérů bychom měli hodnotit ve většině př́ípadů jako pravdivé, případně opodstatněné na základě určité sítě přesvědčení, kterou máme $\mathrm{k}$ dispozici. 4) Jazyk je produktem darwinovského př́rodního výběru.

\section{ANTROPOLOGIE A DARWINISMUS}

Myšlenka evoluce a přirozeného výběru umožňuje vysvětlit, jak fungují struktury v lidském mozku - „jedná se o zastřešujicí teorii, podle které jsou biologové schopni porozumèt původu lidských bytostí, struktuře a funkci člověka, jak fungují orgány $v$ těle člověka, jejich struktuře a funkci a jaký je vztah mezi lidmi a zbytkem živočišné ř́iše (Freese 2013,2). Většina sociálních vědců se tváríi, jako by Darwin vůbec neexistoval a jeho teorii zcela opomíjejí (Dawkins 2014, 1). Všechny lidské subjekty jsou ovládány geny a jsou směrovány k jednomu hlavnímu cíli - přežít. Pro přežití je nezbytné zachování našich genů a toho docílíme jedině prostřednictvím reprodukce. Pokud máme uspokojivou evoluční teorii, která funguje při vysvětlení všech biologických aspektů, nebo alespoň většiny $\mathrm{z}$ nich, proč bychom měli hledat teorie jiné - neopodstatněné? Pokud je lidské chování řízeno mozkem, je nutno zaměřit se při vysvětlení takového jednání právě na mozek a jeho procesy. Abychom poskytli konečné vysvětlení o charakteru lidské společnosti, je třeba směřovat svůj zájem - záměr právě k darwinismu a filozofii mysli. Většina sociálních vědců však myš- lenku darwinismu odsouvá nebo ji při svých výzkumech vůbec nezohledňuje. Výsledek takového počínání u sociálních vědců může být velmi prostý - nedostatečná znalost biologie nebo neochota se tímto nepostradatelným lidským aspektem zabývat. Někteří sociální vědci dokonce tvrdí, že inteligence, emoce či propoziční postoje jsou vůči zákonům př́rody imunní vzhledem $\mathrm{k}$ tomu, že pro antropologii jsou stěžejní společenské jevy. Všechny společenské jevy potom mají znovu své zakořenění v evoluční minulosti, proto můžeme každý fenomén opodstatnit na základě znalosti událostí minulých. Tato myšlenka je velmi podobná evolucionismu, nicméně z něj značným způsobem vybočuje. Zohlednění politického prostředí má za následek to, že nedochází k vyzdvihování společnosti jedné nad společnost jinou - v očích evolucionisty méně vyspělou nebo také primitivní. Kultura, instituce a normy mohou vykazovat propastné rozdíly napříč společnostmi. Společnosti se vyvíjejí podobně, pokud jde o vývoj člověka podle evoluční teorie, ovšem odlišný vývoj probíhá zejména v rychlosti pokroku, mnohdy až šokujícím tempem.

\section{NATURALISTICKÝ KOREKTIV}

Vlivem těchto postmoderních směrů se antropologie ocitla $\mathrm{v}$ krizi, ze které je třeba ji vymanit, podrobit revizi a navést ji zpět $\mathrm{k}$ vědeckému směřování. Antropologie 21. století je v současné podobě možné označit za postmoderní.

Postmodernismus vznikl jako kritický směr k současným pořádkům ve světě. Nespokojenost s antropologickým směrováním a obava $\mathrm{z}$ etnocentrismu vedla $\mathrm{k}$ formování tohoto směru, který se domníval, že našel cestu, jakou by se mohla disciplína ubírat. Podle postmodernistů se během poválečné éry objevovaly myšlenky, které poukazovaly na odlišnosti v kulturách zpơsobem, jenž byl vyhodnocen jako problematický z pohledu etnocentrismu. Jednalo se o užití výrazů jako je primitivní, méně vyspělý, rozvojový a třetí svět pro označení lidí, jejich kořeny nesahají do evropské civilizace (Oldani 1998, 86). Snaha vymanit se ze spárů etnocentrismu vedla $\mathrm{k}$ podpoře interpretatitivních přístupů.

$\mathrm{Na}$ začátku jsme definovali, co je typické pro naturalismus ve filozofii, nyní si shrneme fakta o současném stavu antropologie a ukážeme, jakým směrem by se měla ubírat v naturalizovaném pojetí.

Rosenberg poznamenává, že pokud sociální věda nedochází k žádným pokrokovým výsledkům, možná její vědecká metoda není dostatečně vědecká. Je tedy potřeba, aby si osvojila metody, jež budou odkrývat zákonitosti, které nám pomohou lépe predikovat lidské jednání. Do jaké míry je však možné lidské jednání predikovat? Podle Daniela Dennetta mají všichni lidé schopnost interpretovat a do jisté míry předpovídat jednání sociálních aktérů ve svém okolí. Tyto schopnosti se odvíjejí od znalostí pravidel, jež odhalujeme díky kauzálnímu vysvětlení pravidelností. Dále potom touze porozumět a schopnosti predikovat na základě předchozí znalosti či zkušenosti (Dennett 2016, 74).

Oponenti scientifického přístupu tvrdí, že není možné vy- 
světlit kauzálně lidské jednání, a to hned z několika důvodů. Hlavní argument spočívá v tvrzení, že vše, co se týká člověka, závisí na jeho svobodné vůli. Jestliže máme svobodnou vůli, potom není možné, aby naše jednání podléhalo nějakým zákonům nebo pravidelnostem. Tento přístup je však poněkud problematický a těžko obhájitelný. Jednak proto, že problém svobodné vůle je dlouho rozebíraným kontroverzním tématem a myslitelé, kteří se tímto problémem zabývají, doposud nepřinesli žádné uspokojivé vysvětlení otázky svobody vưle, a jednak proto, že tento názor vede ke skepsi, tj. pokud opravdu lidské jednání nepodléhá žádným zákonitostem, pak jej nelze vědecky vysvětlit, a tak nemůžeme mít žádnou vědeckou teorii lidského jednání (Rosenberg 2012, 117-118). Jenže přijetím této teorie se připravujeme o možnost predikovat lidské jednání nebo jej vůbec správně uchopit.

Cíl antropologického bádání bychom měli soustředit na následující základní prvky týkající se metodologie, tj. vytvořit modely jednání, která můžeme empiricky generalizovat a $\mathrm{z}$ toho formulovat zákony. Tohle je způsob, jakým pracuje prrírodní věda. Nyní se podíváme na to, proč je důležité zaměřovat se na pravidelnosti a $\mathrm{z}$ těch vytvářet empirické generalizace. Postupy užívané ve vědě se řídí vždy podle stanovených pravidel, tzn. vysvětlení, předpoklad a testování hypotéz. $\mathrm{Na}$ základě testování těchto hypotéz jsme schopni dedukovat předpoklady, které se ověrují prostřednictvím experimentu (srov. Popper 2000, 107).

Vrat’me se tedy zpět k jazyku. Bylo řečeno, že významy si člověk osvojuje tzv. hypoteticko-deduktivní metodou, tj. stejnou metodou, jakou uživá prrírodní věda. Správnost zkoumaného výrazu odhalíme prostřednictvím ostentativního ověřování korespondence výrazu s entitou. Jinými slovy, když se snažím rozšifrovat výraz, hledám zákonitosti a pravidelnosti, které mi pomohou odhalit významy výrazů. Rosenberg ukazuje, že odhalování zákonitostí v lidském chování je poněkud komplikovanější, protože lidské jednání nemá žádná psaná pravidla, ta jsou spíše implicitního charakteru (Rosenberg 2012, 119). Dále uvádí příklad takovýchto implicitních pravidel na situaci, kdy užíváme gesta k vyjádření souhlasu (pokývání hlavou) a nesouhlasu (potřesení hlavou do strany). Naučit se rozpoznávat tato gesta je základní předpoklad $\mathrm{k}$ tomu naučit se jazyk. A to nás posouvá ještě dál. Přri zkoumání určité společnosti potřebujeme pochopit pravidla a normy, které udávají významy pro jejich společnost. Znalost těchto nepsaných pravidel je nutnou podmínkou úspěšné lidské komunikace (Rosenberg 2012, 121). Jazyk je základním prostředkem, jenž rrídí naše jednání - všechny normy a zákony jsou formované v jazyce a udávají chod celé společnosti. Pravidla vysvětlují lidské jednání. Chování tedy vysvětlujeme jednak pomocí pravidel, která se v lidském chování nacházejí, a jednak pomocí kauzálních vztahů. Pokud se lidské jednání řídí určitými pravidly, znamená to, že pokud není jedincem pravidlo dodrženo, následuje trest. $Z$ toho vyplývá generalizace:

„Pravidlo $R$ je vždy dodržováno, nebo je jeho narušitel potrestán." (Roenberg 2012, 122).

Jakým způsobem antropolog rozumí lidskému jednání? Jak již bylo řečeno, antropolog se snaží jej pochopit prostřednic- tvím jejich jazyka, tzn. učí se pravidlům zkoumaného jazyka. Rosenberg zmiňuje, jak důležitou roli hraje při zkoumání lidského jednání princip vstřícnosti. Tvrdí, že pokud dojde k sestavení překladové př́ručky, na jejímž základě zjištujeme, že výrok, který nám domorodec ř́ká, je nepravdivý, pak chyba musí být na naší straně, tj. v př̀kladu. Mohlo by to samožrejmě znamenat, že člověk je zcela iracionální, ale princip vstřícnosti nás zavazuje $\mathrm{k}$ tomu, abychom interpretovali domorodce jako racionálního. $Z$ toho vyplývá, že námi sestavená překladová příručka je chybná a je třeba ji revidovat. Osvojení jazyka je tedy úplně prvním předpokladem k pochopení ostatních pravidel, jež činí jejich chování smysluplnější a pochopitelnější (Rosenberg 2011, 126). Jedná se o základní klíčovou metodu antropologického výzkumu. Po naučení se jazyku a pochopení pravidel, která zkoumaná společnost má, se nacházíme už jen krůček od porozumění náboženským rituálům nebo hierarchii ve společnosti.

Vědeckému př́ístupu bývá ze strany interpretativistů vytýkána prŕílišná exaktnost a zkoumání zřejmých událostí, konkrétně při zkoumání lidských subjektů tak může být snadno přehlédnut skrytý kontext, tj. ironický tón, spiklenecké mrknutí - jak ukazuje Cliford Geertz v knize Interpretace kultur. Jakým způsobem se $\mathrm{k}$ tomuto problému staví Gilbert Ryle? V případě spikleneckého mrknutí se jedná o kód, který je sdělován za účelem rozluštění, je směřován adresátovi, jenž je schopen tento kód rozluštit. Pokud někdo jeho počínání napodobuje, je jeho záměr neúspěšný, protože tento kód v sobě nenese žádný význam, ale redukuje se na pouhý fyzický pohyb, tj. zředěný popis. Intence v tomto př́padě hraje zásadní roli. Zhuštěný popis antropolog nevytváŕí, ale zasazuje empirickou evidenci do určitého kontextu. Cílem není mnohovrstevné vytváření interpretací, ale odhalení té správné.

„Podle naturalizované epistemologie bychom od filozofie poznání neměli žádat víc než jen prostý popis toho, jak na základě evidence, která nám je dostupná, dokážeme vytvořit nějakou uspokojivou teorii o podobě a fungování světa. A tento popis se musí opírat o tu nejlepši teorii, kterou máme k dispozici: o současnou vědu " (Quine 1994, 58).

Abychom mohli antropologický výzkum provádět co možná nejpřesněji, domníváme se, že je třeba přijmout naturalistický př́stup do metodologického základu a řídit se evidencí a poznatky, které je možné empiricky ověřit. Jako teoretické východisko nám slouží Quinova teorie naturalizované epistemologie.

\section{LITERATURA}

Alcock, John (2001): The Triumph of Sociobiology. New York: Oxford University Press.

Baker, G. P. - Hacker, M. S. (2009): Wittgenstein: Rules, Grammar and Necessity. Wiley-Blackwell.

Boghossian, Peter (2006): Fear of Knowledge: Against Relativism and Constructivism. Oxford University Press.

Braddon-Mitchell, David - Nola, Robert ed. (2009): Conceptual Analysis and Philosophical Naturalism. Cambridge, Mass: MIT Press,

Kuznar, Lawrence (2008): Reclaiming a Scientific Anthropology. Altamira Press, Walnut Creek. 
Clifford, James - School of American Research, ed. (2008): Writing Culture: The Poetics and Politics of Ethnography. Berkeley: University of California Press.

Craig, William Lane - Moreland, James Porter, ed. (2002): Naturalism: A Critical Analysis. New York: Routledge.

Davidson, Donald (2004): Problems of Rationality. Oxford University Press.

Davidson, Donald (2006): The Essential Davidson. New York: Oxford University Press.

Davidson, Donald (2004): Subjektivita, Intersubjektivita, Objektivita. Praha: Filosofia.

Dawkins, Richard (2006): The Selfish Gene. Oxford University Press.

Dennett, Daniel (2013): Intuition Pumps: and Other Tools for Thinking. Penguin Books.

Doherty, Joe, Elspeth Graham - Malek, Mo (1992): Postmodernism and the Social Sciences. Palgrave Macmillan.

Freese, Jeremy. „What should Sociology do About Darwin?Evaluating some potential Contributions of Sociobiology and Evolutionary Psychology to Sociology.

Geertz, Clifford (2002): Interpretace Kultur. Praha: Slon, 2002.

Kincaid, Harold, ed. (2012): The Oxford Handbook of Philosophy of Social Science. Oxford Handbooks. Oxford: Oxford University Press.

Kim, Jaegwon (2011): Philosophy of Mind. Westview Press.

Knowles, Jonathan (2003): Norms, Naturalism and Epistemology. London: Palgrave Macmillan UK.

Kuhn, Thomas (1997): Struktura vědeckých revolucí. Praha: Oikoymenh.

Melford E. Spiro (1986): „Cultural Relativism and The Future of Anthropology“. American Anthropology 1(3), 259-286.

Melford E. Spiro (1996): „Postmodernist Anthropology, Subjectivity, and Science: A Modernist Critique“. Comparative Studies in Society and History 3 (4), 759-80.

Oldani, Michael (1998): „Postmodernism and Anthropology: Conflict or Cooperation?“. Kroeber Anthropological Society Papers, 83(1), 84-101.

Peregrin, Jaroslav (2011): Člověk a pravidla: kde se berou rozum, jazyk a svoboda. Praha: Dokořán.

Peregrin, Jaroslav (2000): Význam a struktura. Praha: Oikoymenh.

Pinker, Steven (2013): Language, Cognition, and Human Nature. Oxford: Oxford University Press.

Pinker, Steven. (2004): „The Blank Slate. The Modern Denial of Human Nature“. Tijdschrift Voor Filosofie 66(4), 765-767.
Pinker, Steven (1995): The Language Instinct. Harper Perennial UK.

Pinker, Steven - Bloom, Paul (1990): „Natural Language and Natural Selection". Behavioral and Brain Sciences, 13 (4).

Popper, Karl R. (2000): Bída Historicismu. Praha: Oikoymenh.

Putnam, Hilary - Rorty, Richard (1997): Co po metafyzice?; Hilary Putnam a Richard Rorty o realismu a relativismu. Bratislava: Archa.

Quine, Willard Van Orman (2012): Word and Object. New ed. Cambridge, Mass: MIT Press.

Quine, Willard Van Orman (1994): Od Stimulu k Vědě. Hermann\&synové.

Quine, Willard Van Orman (2006): „Naturalizovaná epistemologie“ Vybrané články k ontologii a epistemologii. Plzeň: Západočeská Univerzita.

Quine, Willard Van Orman (2002): Od stimulu k vědě. Praha: Filosofia.

Rorty, Richard (1979): Philosophy and the Mirror of Nature. Princeton: Princeton University Press.

Rosenberg, Alexander (2006): Darwinian Reductionism, or, How to Stop Worrying and Love Molecular Biology. Chicago: University of Chicago Press.

Rosenberg, Alexander (2012): Philosophy of Social Science. CO: Westview Press.

Sperber, Dan (1996): Explaining Culture: A Naturalistic Approach. Cambridge, Mass: Blackwell.

Welsch, Wolfgang - Singer, W. - Wunder, André, ed. (2011): Interdisciplinary Anthropology: Continuing Evolution of Man. New York: Springer.

Zimmer, Carl, (2001): Evolution: The Triumph of an Idea. New York: HarperCollins.

\section{AUTORKA}

Drcmánková, Karolína vystudovala Ph.D. oboru etnologie na FF UK. Výzkumný záměr se specializuje na propojení poznatků z filozofie vědy a kvalitativní metodologií antropologického výzkumu.

Kontakt: Mgr. Karolína Drcmánková, Ph.D. email: drcmankova@ gmail.com 